\title{
Haditechnikai bemutató Budaörsön
}

A Magyar Honvédelem Napja alkalmából rendezett látványos, nagyszabású, haditechnikai és légi bemutatót a Magyar Honvédség 2019. május 18-19-én. A kétnapos eseményen a Budaörsi Repülőtérre több mint 70 ezer ember látogatott ki. Az érdeklődők megtekinthették és kipróbálhatták a Honvédség által használt, és nemrég beszerzett különböző technikai eszközöket. A toborzósátor sok fiatalt vonzott, és a rendezvényen változatos programokkal igyekeztek felhívni a figyelmet a hazáért való szolgálat fontosságára.

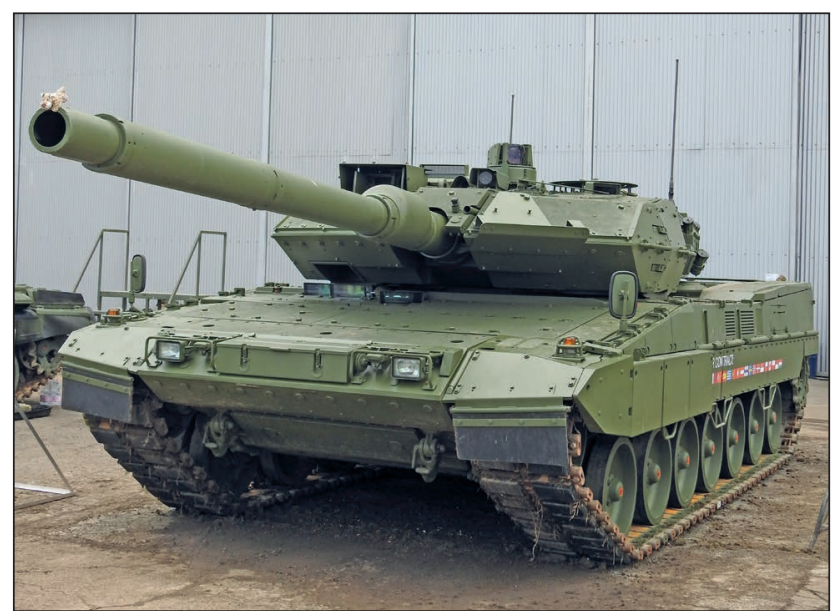

1. ábra. A Leopard 2A7+ harckocsi kategóriájában a világ egyik legkorszerübb eszköze. Rendszeresítésével a Magyar Honvédség harckocsizói olyan új képességekhez jutnak mint a körkörösen megerősített páncélzat és a teljes lefedettségű éjjel-nappali kilátás (Fotó: HM Zrínyi Kft. Dévényi Veronika)

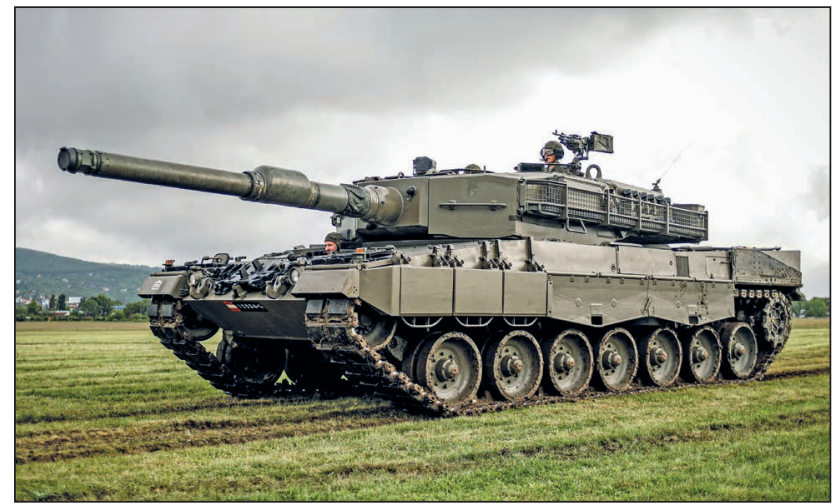

2. ábra. A Leopard 2A4 harckocsi. Bár az 1980-as évek második felében gyártották, a térségben még így is az egyik legkiválóbb adottsággokkal rendelkezó harckocsi, amelybő́l Magyarország a tervek szerint 12 darabot lízingel kiképzési és oktatási célokra (Fotó: HM Zrínyi Kft. Dévényi Veronika)

\footnotetext{
ORCID: 0000-0002-5418-2415
}

** ORCID: 0000-0001-5524-6735

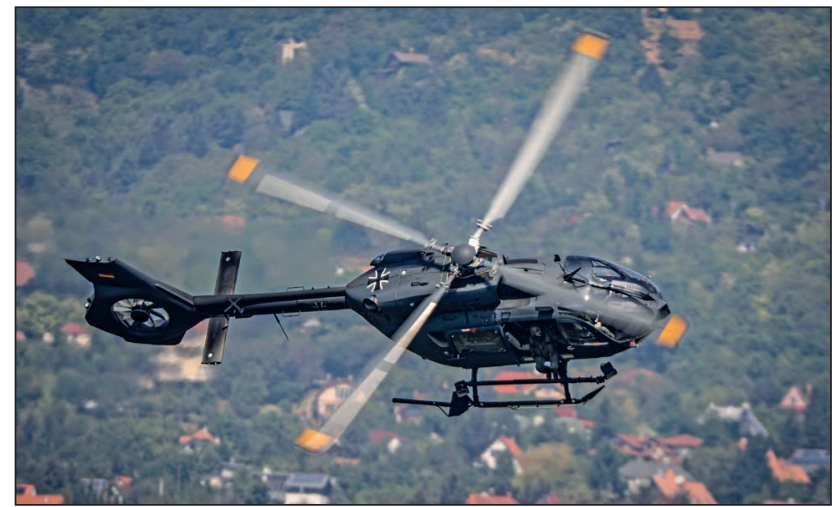

3. ábra. Az Airbus H145M helikopter az egyik legjobb könnyühelikopter a világon. Képességeit bizonyítja, hogy a típus korábbi változatait az amerikai hadsereg is rendszeresítette. A hazai logisztikai kiszolgálását megkönnyíti, hogy az Országos Mentőszolgálat is Airbus helikopter-változatokat üzemeltet (Fotó: HM Zrínyi Kft. Dévényi Veronika)

A megnyitón Németh Szilárd, a Honvédelmi Minisztérium miniszterhelyettese ismertette, hogy a Zrínyi 2026 honvédelmi és haderőfejlesztési program keretén belül 3500 milliárd forintot fordítanak haderőfejlesztésre. A fejlesztési és modernizációs folyamatok során a légi és szárazföldi haderő mellett a logisztika, a katonai-egészségügyi és a vezetési rendszer is megújul. A bemutatón megjelenő eszközök, mint pl. az Airbus H145M helikopter, a szárazföldi haderőnél új páncélos eszközök, mint pl. Leopárd 2A7+ harckocsi, PzH 2000 önjáró löveg rendszeresítése folyamatban van, továbbá megújulnak a könnyű páncélvédett kerekes terepjáró járművek is.

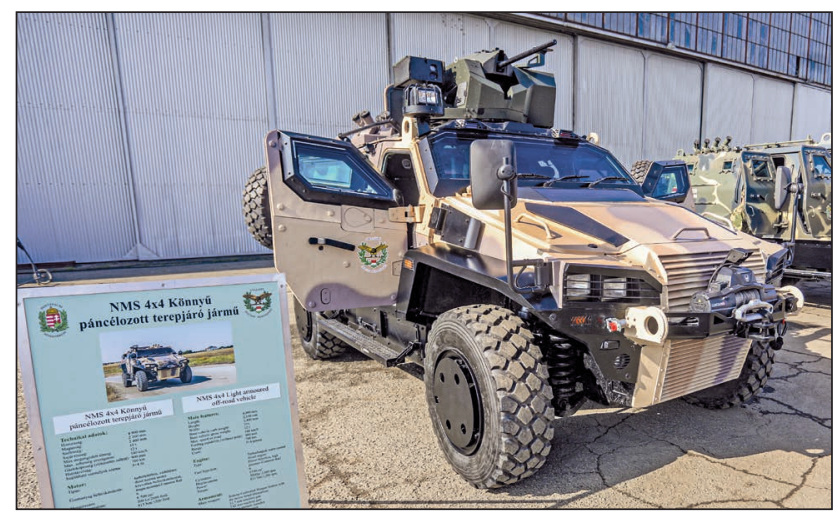

4. ábra. Az NMS 4x4 könnyű páncélozott terepjáró jármű a jól átgondolt tervezésnek köszönhetöen, monokróm „V” alváz, kompozit modulok még egy aknarobbanással szemben is megóvják a személyzetet. Növeli a védettséget a $221 \mathrm{~kW}$ (300 LE) motorteljesítmény és a $140 \mathrm{~km} / \mathrm{h}$ végsebesség (Fotó: HM Zrínyi Kft. Dévényi Veronika) 


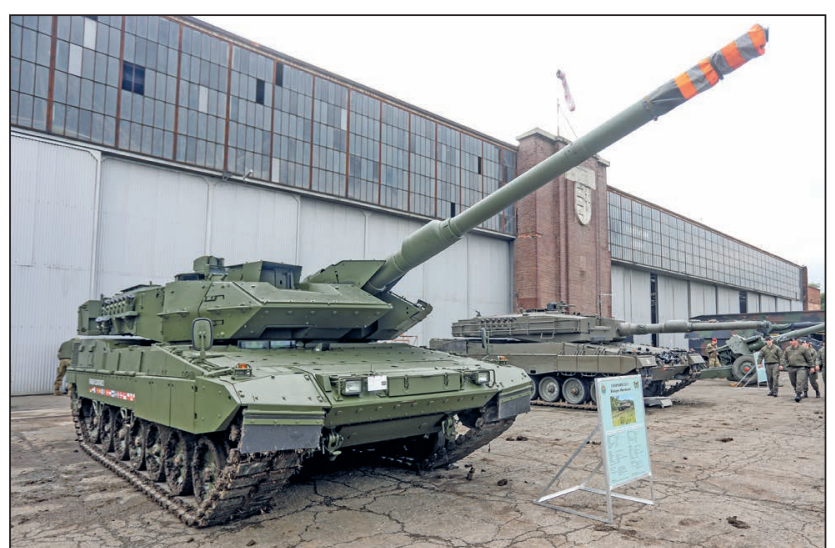

5. ábra. A Leopard 2 harckocsicsalád legújabb, legkorszerübb változata az A7+ verzió. Érdemes megfigyelni a föfegyverzetet, a maximális állásszögre emelt $120 \mathrm{~mm}$-es sima csővű löveget, amely végét ekkor még takaróponyvával fedtek az időjárás viszontagságai miatt (Fotó: HM Zrínyi Kft. Dévényi Veronika)

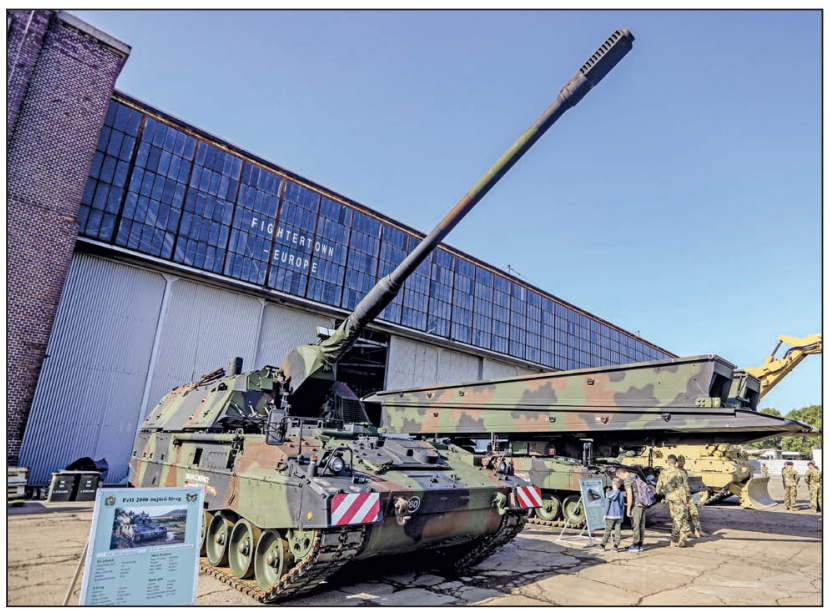

6. ábra. A PzH 2000 önjáró löveggel, a világ élvonalába tartozó fegyverrel a honvédségben újra megjelenik az önjáró tüzérség. A PzH 2000 digitális lőelemképző rendszerével „sebészi pontoságú” tűzcsapást mérhet, akár 30 km-es távolságban felderített célokra is (Fotó: HM Zrínyi Kft. Dévényi Veronika)

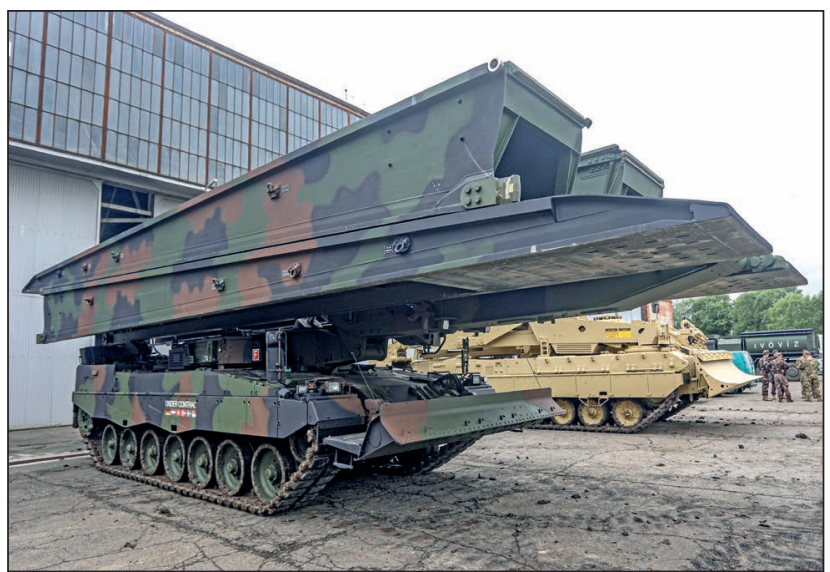

7. ábra. A Leopard Leguan hídvető harckocsival könnyen és gyorsan áthidalhatók a múszaki zárak, vízmosások és kisebb folyók. A Leguan által telepített hidakon átkelve a Leopard 2-es harckocsik és más jármúvek folyamatos mozgásban maradhatnak (Fotó: HM Zrínyi Kft. Dévényi Veronika)

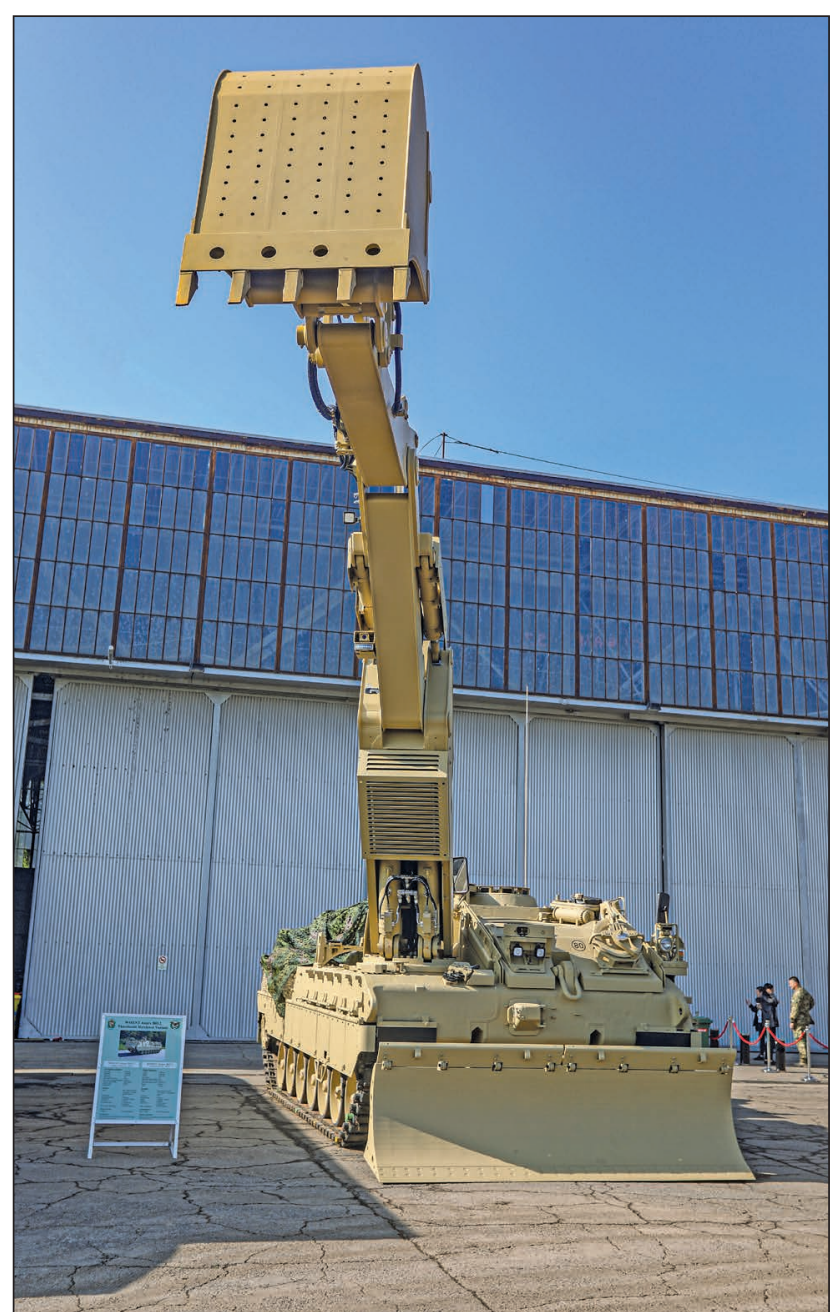

8. ábra. A Wisent 2-es nehéz müszaki mentő és akadályelhárító jármú kinyújtott markoló kanállal. A Leopard 2-es harckocsi alvázára épített jármü követi azt a páncélosok tervezésében elfogadott „családelvet”, amely szerint az műszaki járműveket a harckocsikkal azonos alvázra kell telepíteni, hogy ezáltal ugyanolyan mozgékonyak lehessenek, és együtt haladva támogathassák a hadmúveleteket (Fotó: HM Zrínyi Kft. Dévényi Veronika)

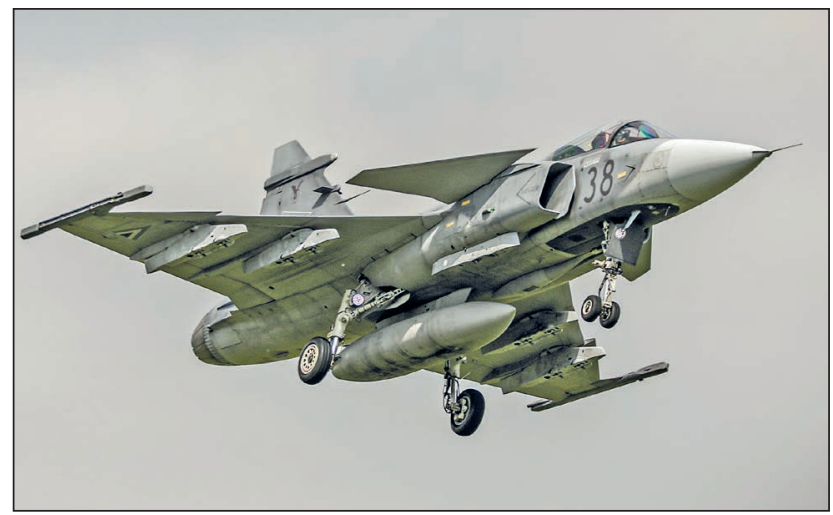

9. ábra. A Magyar Légierő JAS 39 C vadászgépe nyitott futómúvekkel, alacsony sebességú áthúzás közben. A korszerú vadászgépekkel a honvédség megfelel a NATO-elvárásoknak. Ezt bizonyítja, hogy a NATO szerződésben biztosított Balti Air Policing kontingensben képesek nemcsak a hazai, hanem a balti államok légvédelmét is ellátni (Fotó: HM Zrínyi Kft. Dévényi Veronika) 